Удк 336.648:336.71

JEL classification: S36, F25, F12

\section{Олена БЕНЗАР}

Донецький національний університет імені

Василя Стуса, Україна

E-mail: lenabenzar@gmail.com

https://orcid.org/0000-0003-4462-204X

\section{Олександра ЛАКТІОНОВА}

доктор економічних наук, доцент,

завідувач кафедри фінансів та банківської справи,

Донецький національний університет імені Василя Стуса, Україна

E-mail: laktionova.loa@donnu.edu.ua https://orcid.org/0000-0001-6472-6503

Scopus Author ID: 35758779200

(C) Олена Бензар, Олександра Лактіонова, 2019

Отримано: 24.05.2019 p.

Прорецензовано: 31.05.2019 р.

Рекомендовано до друку: 12.06.2019 р.

Опубліковано: 26.06.2019 р.

\section{cc) (†) (8)}

Ця стаття розповсюджується на умовах ліцензії Creative Commons Attribution-NonCommercia 4.0, яка дозволяє необмежене повторне використання, розповсюдження та відтворення на будь-якому носії, за умови правильного цитування оригінальної роботи.
Олена Бензар (Україна)

олександра Лактіонова (Україна)

\section{ФIНАНСОВІ ОБМЕЖЕННЯ НЕФІНАНСОВИХ КОРПОРАЦІЙ ЯК ЧИННИК ФІНАНСОВОÏ СТАБІЛЬНОСТІ БАНКІВСЬКОї СИСТЕМИ}

\section{Анотація}

Вступ. В умовах активного розвитку фінансового сектору економіки та високого попиту на розширення своїх можливостей з боку нефінансових корпорацій виникає потреба в залученні ними додаткового капіталу, що виступає причиною для пошуку певного балансу та встановлення взаємовигідних економічних відносин. Явище фінансових обмежень як низька спроможність компанії залучати додатковий зовнішній капітал відіграє досить актуальну роль у сучасних умовах, адже пошук шляхів доступу до позикового капіталу з боку нефінансового сектору із одночасним дотриманням фінансової стабільності банківської системи $є$ базисом для побудови стійких економічних зв'язків на фінансовому ринку та безпечного зростання економіки країни взагалі без пропагування асиметричного кредитного циклу. Для такого циклу стадія відновлення попиту та пропозиції на ринку відбувається швидше.

Мета. Обґрунтування теоретичних основ явища фінансових обмежень та його ключових каналів взаємовпливу із станом банківської системи та її фінансовою стабільністю зокрема.

Результати. До наукових результатів роботи слід віднести визначення основних каналів взаємовпливу фінансових обмежень нефінансових корпорацій та фінансової стабільності банків, виявлення напрямів зниження фінансових обмежень серед суб'єктів господарювання з метою розширення можливостей до активізації їх економічного розвитку, використання яких дозволить підвищити ґрунтовність рішень щодо розширення доступу до капіталу з боку банків та визначення їх впливу та системні фінансові ризики та, відповідно, фінансову стабільність банківської системи.

DOI: https://doi.org/10.35774/econa2019.02.005

Бензар О., Лактіонова О. Фінансові обмеження нефінансових корпорацій як чинник фінансової стабільності банківської системи. Економічний аналіз. Тернопіль. 2019. Том 29. № 2. С. 5-14.

Ключові слова: фінансові обмеження; фінансова стабільність; банківська система; нефінансові корпорації; доступ до фінансів. 
UDC 336.648:336.71

JEL classification: S36, F25, F12

\section{Olena BENZAR}

Vasyl' Stus Donetsk National University, Ukraine E-mail: lenabenzar@gmail.com https://orcid.org/0000-0003-4462-204X

\section{Aleksandra LAKTIONOVA}

Doctor of Sciences (Economics), Associate Professor,

Head of the Department of Finance and Banking, Vasyl' Stus Donetsk National University, Ukraine E-mail: laktionova.loa@donnu.edu.ua https://orcid.org/0000-0001-6472-6503 Scopus Author ID: $\mathbf{3 5 7 5 8 7 7 9 2 0 0}$

(C) Olena Benzar, Aleksandra Laktionova, 2019

\section{Received: 24.05.2019}

Revised: 31.05.2019

Accepted: 12.06.2019

Online publication date: 26.06 .2019

This is an Open Access article, distributed under the terms of the Creative Commons AttributionNonCommercial 4.0 license, which permits unrestricted re-use, distribution, and reproduction in any medium, provided the original work is properly cited.
Olena Benzar (Ukraine)

Aleksandra Laktionova (Ukraine)

\section{FINANCIAL CONSTRAINTS OF NON-FINANCIAL CORPORATIONS AS A FACTOR OF FINANCIAL STABILITY OF THE BANKING SYSTEM}

\begin{abstract}
Introduction. Under the conditions of an active development of financial sector and the demand for expanding its capabilities by business entities there is a need to attract additional capital. It is a reason for finding a certain balance and arrangement of mutually beneficial economic relations. The phenomenon of financial constraints as the company's low ability to attract additional external capital plays a crucial role in modern non-perfect market. The searching for ways of expansion of access to credit by the non-financial corporate sector under the requirement of financial stability support of the banking system is a basis for building sustainable economic ties on the financial market and safe growth of the country's economy without propagating the asymmetric credit cycle. For such a cycle, the stage of recovery of supply and demand in the market is faster and more stable.

Purpose. The justification of theoretical basis of the phenomenon of financial constraints and its key channels of interaction with the financial performance of the banking system and its financial stability.

Results. The scientific results of work are the detection of the main channels of mutual influence of the financial constraints of non-financial corporations and the financial stability of banks, identification of directions for reducing financial constraints among economic entities in order to expand the possibilities for activating their economic development, that allows to increase the comprehensiveness of decisions on expansion of access to capital of banks and determine their impact on systemic financial risks and financial stability of the banking system in overall.
\end{abstract}

Benzar, O., Laktionova, A. (2019). Financial constraints of non-financial corporations as a factor of financial stability of the banking system. Economic analysis, 29 (2), 5-14.

DOI: https://doi.org/10.35774/econa2019.02.005

Keywords: financial constraints; financial stability; banking system; non-financial corporations; access to finance.

\section{Вступ}

Сучасна економічна ситуація в Україні характеризується нестабільністю макроекономічного середовища, зокрема суттєвою волатильністю показників фінансового ринку, поступовим відновленням банківської системи після фінансової кризи на фоні суттєвої асиметрії кредитного циклу. Подальший економічний розвиток країни, активізація інвестиційних процесів у реальному секторі економіки є критично важливим питанням у найближчий період часу. У цьому аспекті розширення доступу до капіталу всіх суб'єктів господарювання, підвищення пропозиції на кредитні ресурси із тенденцією зниження їх вартості, у тому числі за рахунок їі ризикової складової (премії за ризик), повинно стати драйвером економічного розвитку.

Інтерес до феномену фінансових обмежень, що $€$ переважно 
www.econa.org.ua

внутрішньою характеристикою суб'єктів нефінансового сектору, більш розповсюджений серед іноземних дослідників. Серед науковців, що займаються дослідженням проблем фінансових обмежень, слід назвати Бадурі С., Баума К., Ву В., Зінгалеса Л., Каплана С., Панкову Є., Раджана Р., Талавейри А., Тєплову Т., Фаззарі С., Шаферба Д. Питання фінансових обмежень як складової фінансового розвитку країни досліджують Бек Т., Вейц А., Грінвальд Б., Думіргунт-Кунт А., Стігліц Дж., Хонокан П. та інші.

Водночас залишається невирішеною низка теоретичних та практичних проблем, пов'язаних із визначенням та виміром фінансових обмежень корпорацій, урахуванням особливостей їх формування та проявів в Україні, їх зіставленням із проблемою доступу до капіталу та впливу на фінансову стабільність банківської системи.

\section{Мета та завдання статті}

Метою дослідження виступає обгрунтування теоретичних засад щодо визначення змісту фінансових обмежень та виявлення їх безпосереднього та опосередкованого взаємозв'язку 3 фінансовою стабільністю банківської системи.

Вищезазначена мета передбачає виконання таких завдань: узагальнення теоретичних основ фінансових обмежень та оцінка їх впливу на фінансову стабільність банківської системи; пошук альтернативних шляхів та ключових факторів підвищення фінансової стабільності банківської системи.

\section{Виклад основного матеріалу дослідження}

Рівень розвитку та ефективність функціонування фінансової системи країни має вирішальне значення для зростання ділової активності та продуктивного використання ресурсів підприємствами та населенням. Зокрема, рівень стабільності та розвитку фінансової системи визначає наявність у суб'єктів господарювання певного доступу до фінансів та, отже, спектр їх можливостей для ефективного залучення та використання фінансових ресурсів. Зазначимо, що існує і зворотній зв'язок та взаємовплив між ним.

Фінансова стабільність - це стан фінансової системи, відповідно до якого вона здатна належним чином виконувати основні функції, такі, як фінансове посередництво та здійснення платежів, а також протистояння кризовим явищам [1]. При цьому фінансова стабільність банківської системи єії ключовою складовою.

Отже, фінансову стабільність можна розглядати як стан системи, у якій фінансові посередники, ринки та ринкова інфраструктура полегшують послідовний рух коштів між вкладниками та інвесторами і, таким чином, сприяють зростанню економічної активності. I навпаки, фінансова нестабільність $\epsilon$ істотним порушенням цього процесу посередництва із потенційно шкідливими наслідками для економіки.

Банківську систему вважають стабільною, якщо вона: 1) полегшує ефективний розподіл фінансових ресурсів у просторі та часі; 2) дозволяє здійснювати оцінку, котирування, розподіл та управління фінансовими ризиками; 3) зберігає здатність до виконання цих надважливих функцій навіть за умов зовнішніх потрясінь або посилення диспропорцій [2]. Порушення фінансової стабільності вказує на проблеми із виконанням відповідних функцій банками.

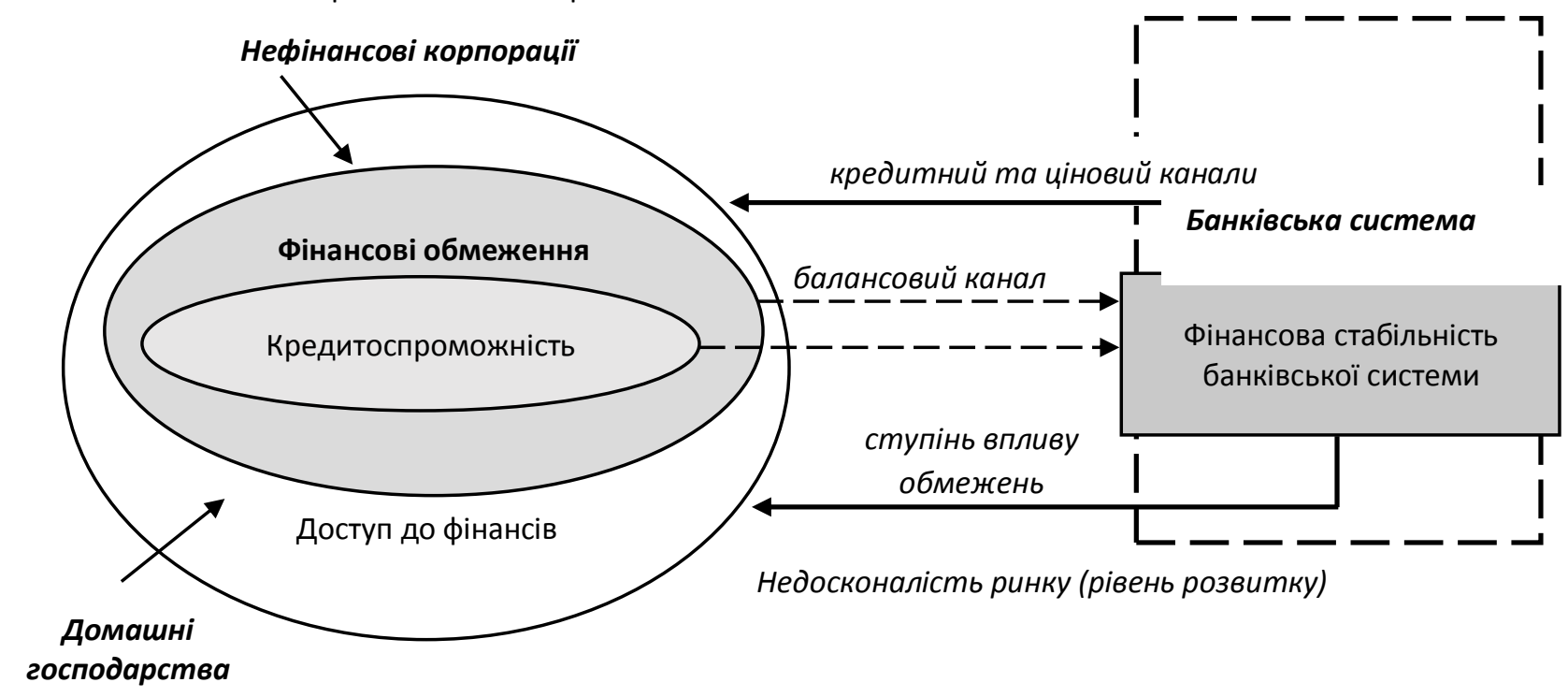

Рис. 1. Взаємозв'язки між феноменом «фінансових обмежень» та фінансовою стабільністю банківської системи 
www.econa.org.ua

Відповідно до звітів фінансової стабільності банківських систем у світовій практиці та, зокрема, звіту НБУ вона характеризується сукупністю певних характеристик самої банківської системи, але не обмежується ними $[3 ; 4 ; 5 ; 6 ; 7]$. Визначення складу чинників фінансової стабільності банківської системи засвідчує критичність врахування ії̈ зв'язку із станом інших інституційних секторів економіки та, зокрема, станом сектору нефінансових корпорацій. Ступінь їх боргового навантаження, рівень покриття фінансових витрат, ефективність діяльності, засвідчуючи їх кредитоспроможність, одночасно, визначають i наявність у них можливостей доступу до фінансів або спроможність до залучення зовнішніх джерел фінансування.

Зазначимо, що явище «фінансових обмежень» (financial constraints) певною мірою можна ототожнити 3 "доступом до фінансів» (access to finance), однак у вузькому розумінні перші виступають внутрішньою характеристикою суб'єктів господарювання, що визначає їх здатність залучати зовнішні фінансові ресурси. На відміну від них, доступ до фінансів як явище характеризує спроможність індивідуумів та суб'єктів господарювання отримувати фінансові послуги та, зокрема, фінансові ресурси [8] або мати широкий доступ до них на основі відсутності цінових та нецінових бар'єрів [9].
На наявність взаємозв'язку між доступом до фінансів і економічним розвитком звертають увагу та емпірично підтверджують його такі вчені, як Р. Раджан і Л. Зінгалез [10], А. Джованні [11]. На їх думку, доступ до фінансування покращує ефективність нових компаній, а також компаній, що належать до більш залежних від зовнішнього фінансування галузей, вони мають більші можливості в країнах із більш розвиненими фінансовими ринками, завдяки ефективному обміну інформацією та управлінням ризиками, а також кращому розподілу ресурсів для прибуткових інвестиційних проектів. 3 іншого боку, фінансові обмеження, які перешкоджають компаніям інвестувати в інноваційні проекти, можливостям зростання або здійсненню реструктуризації капіталу В разі негативних наслідків, негативно впливають на продуктивність, зайнятість, інновації та розрив у доходах.

Як обґрунтування цих впливів фінансових обмежень на розвиток наведемо результати дослідження, проведені фахівцями Світового банку [12], відповідно до яких малі компанії зазнають більших втрат від нереалізованого потенціалу зростання ділової активності від різних фінансових обмежень (та фінансових обмежень як балансового каналу, зокрема), ніж великі компанії (рис. 2).

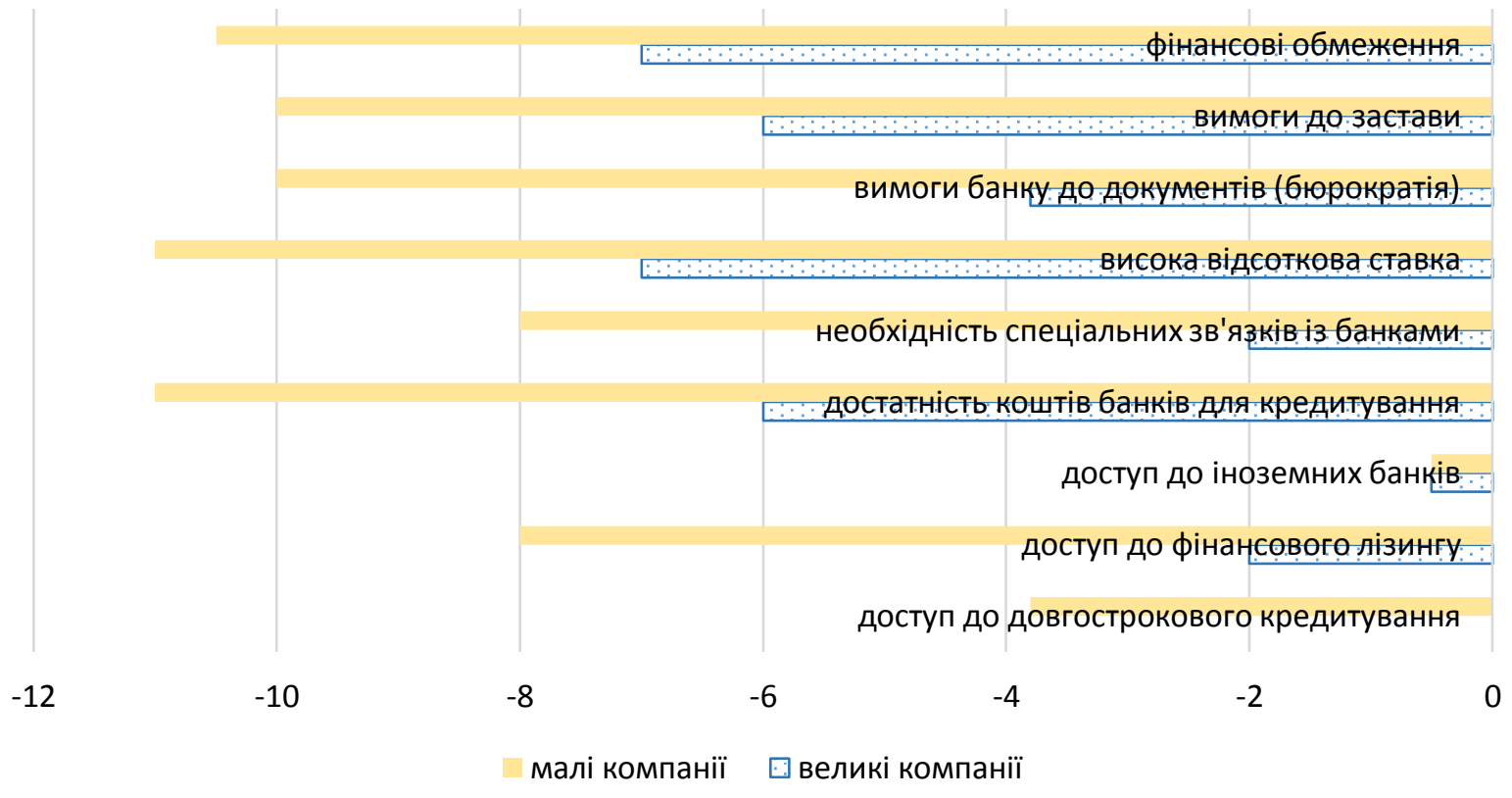

Рис. 2. Вплив доступу до капіталу на ділову активність нефінансових корпорацій (темп зростання) залежно від їх розміру, \%

Натомість взаємозв'язок між фінансовою стабільністю банківської системи і фінансовими обмеженнями нефінансових корпорацій $€$ менш дослідженим феноменом.
3 нашої точки зору, можна виокремити такі ключові канали впливу фінансових обмежень на фінансову стабільність банківської системи:

- канал зростання ділової активності реального сектору через упровадження інвестиційних 
www.econa.org.ua

проектів та, отже, їх рентабельність та попит на капітал;

- канал якості активів (кредитоспроможності) та боргового навантаження (балансовий канал).

I навпаки, основним каналом впливу фінансової стабільності на фінансові обмеження виступає доступ до фінансів.

Наведений механізм обумовлює наявність чіткого багатостороннього зв'язку, що характеризує взаємозалежність фінансових обмежень нефінансових корпорацій та фінансової стабільності банківської системи, яка в кінцевому підсумку впливає на стабільність фінансової системи країни.

Підвищення рівня доступу до фінансів суб'єктів господарювання, тобто зниження їх фінансових обмежень, призведе до покращення фінансової гнучкості підприємств, що збільшить діапазон їх можливостей із залучення додаткових ресурсів, що підвищить фінансову стабільність банківської системи та держави загалом. Цінність цього аспекту визначається також тим, що фінансові обмеження здебільшого $є$ неціновим каналом взаємозв'язку із ринком капіталу, що потенційно не може бути врегульовано тільки шляхом грошово-кредитної політики НБУ.

Проблема фінансових обмежень викликає активний інтерес економістів-аналітиків, що обумовлене підвищенням періодичності настання кризових явищ у світовій економіці. У наукових дослідженнях питання фінансових обмежень викликає бурхливі суперечки, авторами дається різне тлумачення цього поняття. У тлумачному словнику С. І. Ожегова «обмежити» означає поставити в певні рамки, межі, визначити якиминебудь умовами, а також зробити меншим, скоротити охоплення чого-небудь. Відповідно й в основу фінансових обмежень покладена проблема труднощів доступу до чого-небудь, проблема неповної реалізації існуючих можливостей за певних причин.

У теорії корпоративних фінансів під фінансовими обмеженнями розуміють наявність істотних відмінностей у витратах на капітал по внутрішніх (прибуток) і зовнішніх (перш за все, позиковий капітал) джерелах фінансування [1], таким чином, підкреслюючи результат вияву таких фінансових обмежень у вигляді підвищенні ціни ресурсів. Водночас низкою дослідників фінансові обмеження трактуються і як нездатність компанії забезпечувати власними або зовнішніми ресурсами свою інвестиційну діяльність, відштовхуючись тим самим від змістовної їх ознаки. Згідно 3 визначенням Бадурі С., компанії вважаються фінансово обмеженими, якщо витрати на існуючі зовнішні джерела фінансування перешкоджають досягненню оптимального рівня або обсягів інвестицій компанії, якого вона могла $б$ досягти за умови доступності фінансування [12]. А оскільки обсяг інвестицій компанії істотною мірою визначає швидкість ії розвитку і $€$ драйвером економіки загалом, розуміння й упорядкування фінансових обмежень, з якими зустрічаються підприємства на недосконалому ринку, конче потрібно.

Одними з перших, хто звернув увагу на проблему фінансових обмежень, були американські вчені С. Фаззарі й Р. Хаббард, які досліджували природу фінансових обмежень через наявність негативного впливу інформаційної асиметрії на ринку капіталу, яка не дозволяє в разі потреби швидко реструктуризувати капітал компанії. Автори зізнаються, що асиметричність інформації, а, отже, і фінансова обмеженість, найбільшою мірою характерна для нових фірм або для фірм із відносно невеликим обсягом сукупних активів, торгівля акціями яких відбувається поза провідними фондовими біржами регіону та не $\epsilon$ організованою. Що стосується великих нефінансових корпорацій, то вважається, що завдяки наявності публічної інформації $€$ можливість аналізу перспектив їх функціонування і кредитоспроможності, що дозволяє запобігти появі інформаційної асиметрії, привабити інтерес широкого кола інвесторів, а також полегшити доступ суб'єктів господарювання до ринків позичкового капіталу [2].

Б. Грінвальд показує яким чином проблема асиметрії інформації може привести до виникнення «раціонування» кредитів з боку банків [13]. Коли рівень інвестицій стає залежним не стільки від вартості залучення коштів, скільки від їхньої доступності. Переважна кількість фірм буде не в змозі залучити достатній капітал для здійснення навіть високоефективних проектів. Причина в тому, що недосконалий ринок не може адекватно оцінювати ризики інвестиційних проектів компаній і пропонувати по них прийнятний рівень прибутковості. Особливо гостро ця проблема набуває актуальності в періоди фінансової або банківської кризи, відновлення їх фінансової стабільності, що супроводжується делевериджем банків та, відповідно, занадто обережною кредитною політикою банків та «переоцінкою» кредитних ризиків.

Як результат, на недосконалих фінансових ринках розрив у ціні між внутрішніми й зовнішніми джерелами фінансування для фірми стає дуже великим, і компанії змушені використовувати політику ієрархії джерел, яку ще в 1961 р. описав Дж. Дональдсон у межах емпіричного дослідження, що проводилося на базі опитування керівників американських компаній [1]. Згідно з ієрархією основним і більш пріоритетним джерелом фінансування реалізації інвестиційних проектів $\epsilon$ нерозподілений прибуток, далі забезпечені позики, незабезпечені зобов'язання, замикає цей ланцюжок власний залучений капітал. 
www.econa.org.ua

Така фінансова обмеженість приводить до зсуву інвестиційного вибору. Компаніям доводиться вибирати не стільки між ефективними й неефективними проектами, скільки між проектами з доступним фінансуванням.

Ще одним напрямом дослідження формування фінансової обмеженості суб'єктів господарювання $\epsilon$ вивчення впливу рівня фінансового розвитку держави. При цьому під фінансовим розвитком 3 погляду інституціонального підходу, якого дотримується у своєму трактуванні Всесвітній банк, розуміються «фактори, заходи, інститути, що сприяють ефективному фінансовому посередництву й ефективним ринкам, а також більш широкому й глибокому доступу до капіталу й фінансових послуг». Ступінь доступності фінансових ресурсів або фінансових обмежень, у межах цього підходу, розглядається як безпосередній результат рівня розвитку фінансової системи. Найбільшою мірою цей аспект обґрунтовується в дослідженнях А. Демиргук-Кунта й Р. Левина [14], Д. Вулглера [15], Л. Заччіно [16] .

Серед досліджень, присвячених взаємозв'язку цих факторів і доступу до зовнішнього фінансування, слід назвати доробок Деміргук-Кунта А. і Максимовича В., що виявили позитивний взаємозв'язок між ними [17]. Більш пізні їх роботи, а також дослідження із порівняльного аналізу структури капіталу й особливостей структури позикових фінансових ресурсів, проведені Фаном Дж., Тітманом С. і Твітом Д. [18], підтвердили істотний вплив інституціональних факторів (рівня розвитку ринку капіталу, ступеня захисту інвесторів і податкової політики). Саме ці фактори, з їх погляду, пояснюють відмінність величини й структури позикового фінансування суб'єктів господарювання розвинених і країн, що розвиваються, а сама модель фінансової системи, її сконцентрованість на банківському або ринковому фінансуванні, визначають ділову активність нефінансових корпорацій на різних стадіях економічного розвитку. Заслуговують на увагу також розвідки, що визначають тип фінансової системи, що надає більші фінансові можливості для компаній, які мають фінансові обмеження й, відповідно, несуть максимальні витрати за зовнішнім фінансуванням. У цьому аспекті слід виокремити аналіз Раджана Р. і Зінгалеса Л. [10], що виявив закономірність, за якою суб'єкти господарювання галузей, більшою мірою залежних від зовнішнього фінансування, мають більші темпи економічного зростання саме в країнах з більш розвиненою фінансовою системою. Підтвердження цієї гіпотези отримане також у роботах Алмейда X. [19] і Левайна Р. [20], що проводили дослідження на великій вибірці різних країн. Цінність отриманих результатів полягає в підтвердженні важливості рівня розвитку й структури фінансової системи для суб'єктів господарювання, що випробовують фінансові обмеження, і відсутність впливу цих факторів на компанії, що не мають значної відмінності між вартістю внутрішнього й зовнішнього фінансування. Водночас на ролі саме типу (моделі) фінансової системи роблять акцент Баум К., Шаферб Д. і Талавейра А., які визначили, що саме система, орієнтована на банківське фінансування, забезпечує більш легкий доступ до зовнішніх ресурсів компаніям 3 обмеженими фінансовими можливостями [21]. I, навпаки, суб'єкти господарювання в країнах, що тяжіють до ринкового фінансування, більш імовірно будуть зазнавати фінансових обмежень.

Розуміння сутності фінансових обмежень різними авторами здебільшого базується на виборі конкретного показника (показників) або індикаторів (ознак), що сигналізують про їх певний рівень, адже зовнішні зацікавлені суб'єкти не мають повної інформації. Іншими словами, невисокий попит на кредитні ресурси з боку нефінансових корпорацій може спостерігатися не тільки внаслідок обмежень з боку їх пропозиції на кредитному ринку, але і невисоких інвестиційних перспектив у реальному секторі економіки.

Низкою авторів як визначальний параметр внутрішніх фінансових обмежень 3 боку підприємств визначаються стандартні фінансові показники кредитоспроможності - коефіцієнти ліквідності, довгострокової стабільності, Zкоефіцієнт Альтмана [22]. Дослідження показують, що має значення також факт наявності самого кредитного рейтингу [23].

Наступний критерій фінансової обмеженості залежність від банківського фінансування та ступінь залежності від одного постачальника капіталу. Наприклад, компанії, що віддають перевагу банківському фінансуванню, показують в емпіричних дослідженнях більшу залежність інвестицій від змін в операційних грошових потоках. 3 іншого боку, має значення міцність зв'язку із ключовим банком. Що міцніший зв'язок 3 банком для компанії, то менш залежні інвестиції від поточних фінансових результатів [24]. Зіставлення країн також підтверджують цей висновок - для країн з переважно публічним позиковим капіталом (залученим на основі випуску облігацій) чутливість інвестицій до грошових потоків є вищою [25].

Наступним важливим критерієм є розмір компанії. С. Фазарі, Р. Хаббард і Х. Петерсен у своїй роботі показали, що проблема обмеженості капіталу особливо актуальна для невеликих публічних компаній [2]. У зв'язку з тим, що невеликі компанії змушені покладатися в основному на внутрішні джерела фінансування або банківські кредити, саме вони зазнають труднощів із залученням капіталу, зокрема, у періоди 
www.econa.org.ua

економічного спаду. Для цих компаній характерними $€$ низькі дивідендні виплати. У своєму дослідженні автори довели, що під час економічного спаду потенційні джерела одержання кредитних ресурсів для дрібних компаній вичерпуються швидше, ніж для великих компаній, відповідно змінюється й дивідендна політика. Таким чином, наявність фінансових обмежень діагностується в разі низьких дивідендних виплат та виплат власникам. Організації змушені спрямовувати весь прибуток на інвестиції, адже не можуть залучити кошти із зовнішнього ринку.

Водночас американські вчені С. Каплан і л. Зінгалес піддали сумніву наявність згаданого вище прямого зв'язку фінансових обмежень i дивідендної політики [26]. їх дослідження показало, що серед компаній 3 найменшими коефіцієнтами дивідендних виплат 3 вибірки спостерігається слабка залежність між внутрішніми джерелами фінансування й обсягом інвестицій. Отримане протиріччя пізніше у своїй роботі пояснили Г. Алаяніс і А. Мозамдар, які показали, що такі своєрідні висновки С. Каплана й Л. Зінгалеса були отримані завдяки, по-перше, залученню у вибірку компаній з негативним грошовим потоком i, по-друге, незначним розміром вибірки (48 компаній).

Результатом недосконалості фінансового ринку саме і $\epsilon$ розрив у вартості внутрішніх і зовнішніх фінансових ресурсів для суб'єкта господарювання, що позначено вище як основний вияв обмежень.

Складність умов отримання доступу до позичкового фінансування потребують пошуку факторів скорочення фінансових обмежень для всіх суб'єктів господарювання, а також дослідження можливих заходів із покращення доступу до капіталу взагалі. Такі завдання повинні бути нерозривно пов'язані з цілями підвищення рівня фінансової стабільності банківської системи, адже їх негативний взаємовплив через механізм фінансової акселерації в умовах кредитних циклів може суттєво погіршити вплив різних шоків та поглибити кризові явища. Серед інших позитивних ефектів для економіки від зростання доступу до капіталу слід назвати: зростання кредитоспроможності, інвестиційної привабливості та масштабів бізнесу; підвищення мотивації до прозорості та корпоратизації бізнесу; зниження концентрації власного капіталу корпорацій; підвищення рівня конкуренції.

Пошук шляхів зниження фінансових обмежень передбачає постановку конкретних завдань, які доцільно розглядати в рамках окремих напрямів формування політики фінансової стабільності банківської системи - пруденційного нагляду i макропруденційної політики. І оскільки пруденційна політика забезпечує контроль та нагляд за стабільністю та ефективністю діяльності окремого банку, основним ії завданням $\epsilon$ розширення чинників та критеріїв, що враховуються під час визначення рівня кредитного ризику нефінансових корпорацій. Другим рівнем виступає макропруденційна політика, що за обсягом своїх повноважень значно масштабніша, адже фокусується на фінансовій стабільності всієї банківської системи та системних ризиках. Тому до переліку ії завдань можуть входити: розширення методології оцінки та аналізу фінансової стабільності із урахуванням показників доступу до капіталу; урахування фінансових обмежень суб'єктів господарювання під час оцінки шокових впливів на банківську систему та розробка заходів щодо розширення доступу до капіталу.

Оцінка рівня фінансових обмежень базується здебільшого на застосуванні конкретних показників та індексів, які містять конкретний перелік чинників, що безпосередньо виступають індикатором виміру фінансових можливостей нефінансових корпорацій. Так авторським колективом Т. Вайтеда та Дж. Ву [27] був запропонований альтернативний індекс визначення фінансових обмежень, що враховує такі фактори: коефіцієнт Тобіна як змінну, який неоднозначно оцінює вплив збільшення ринкової вартості акціонерного капіталу на ступінь фінансових обмежень; рівень дивідендних виплат; фінансовий леверидж корпорації; розмір компанії (обсяг сукупних активів); рівень розвитку компанії у зіставленні 3 компаніями-аналогами; рівень зростання обсягу продажів.

Умови ведення бізнесу в Україні можуть зумовити розширення переліку чинників виміру фінансових обмежень, що були враховані іноземними науковцями у своїх аналітичних розробках. У результаті оцінка наявності фінансових обмежень у корпорацій під час залучення позичкового капіталу може містити й інші фактори: рівень концентрації капіталу корпорацій, факт входження до холдингової структури, факт наявності комерційного банку у складі холдингу, а також розмір частки необоротних активів компанії в структурі ії балансу.

Вимір можливостей доступу нефінансових корпорацій до зовнішнього капіталу спрямований на аналіз комплексу фінансово-економічних факторів, що впливають на здатність компанії залучати та використовувати позичковий капітал на вигідних умовах, та реалізацію основних заходів пруденційної та макропруденційної політики для забезпечення фінансової стабільності банківської системи.

Із позиції потенціалу використання цього методологічного підходу до оцінки у пруденційній політиці в банківській системі, розглянуто його зіставність із Положенням НБУ «Про визначення 
www.econa.org.ua

банками України розміру кредитного ризику за активними банківськими операціями» [28]. Треба зазначити, що їх спільними критеріями, які враховуються в оцінці кредитоспроможності i кредитного ризику підприємств, є такі: урахування масштабів бізнесу (великий, середній та малий); урахування належності до холдингових структур (у Положенні зазначено про «належність до групи під спільним контролем»); урахування фінансового левериджу нефінансових корпорацій. Однак модель, на відміну від Положення, враховує наступні чинники: виплати власникам (дивідендні виплати); структура та динаміка грошових потоків; темп зростання конкретної компанії у зіставленні із галуззю та темп зростання її доходів; рівень концентрації власності.

Виконання вищезгаданих завдань зорієнтоване на ключову ціль всього процесу 3 розширення можливостей доступу до фінансів і полягає в підвищенні фінансової стабільності банківської системи. Упровадження цього комплексу завдань зумовить втілення в дію й інших економічних ефектів: зростання інвестицій, кредитоспроможності, масштабів малого бізнесу; підвищення мотивації до прозорості та корпоратизації бізнесу; зниження концентрації власного капіталу компаній; зростання конкуренції.

\section{Висновки та перспективи подальших розвідок}

Наявність доступу до капіталу впливає на скорочення фінансових обмежень суб'єктів господарювання та вияв фінансової гнучкості в прийнятті управлінських рішень цими суб'єктами. Система взаємозв'язку фінансової стабільності банківської системи через призму зменшення фінансових обмежень відіграє важливу роль у економічній стійкості та рівновазі суб'єктів господарювання. Постійна оптимізація та налагодження стійких зв'язків між усіма суб'єктами фінансової системи дасть змогу продуктивно розвивати та підтримувати постійну тенденцію до зростання фінансової стабільності банківської системи. Адже розширені можливості доступу до капіталу забезпечують активний розвиток та інвестиційний прогрес усієї економічної системи країни.

\section{СПИСОК ВИКОРИСТАНИХ ДЖЕРЕЛ}

1. Теплова Т. Эмпирическое исследование влияния финансовых ограничений, определяемых размером компании, на инвестиционное поведение на российском рынке. Управление корпоративными финансами. № 4. 2007. С. 212-226.

2. Fazzari S. Hubbard R. G. Petersen B. C. Financing constraints and corporate investment. Brookings Papers on Economic Activity, Vol. 1, 1998. P. 141-195.

3. The Financial Stability Review. European Central Bank. URL: https://www.ecb.europa.eu/pub/fsr /html/index.en.html (Last accessed: 15.12.2018).

4. Financial Stability Report. Bank of England.

https://www.bankofeng land.co.uk/financial-stabilityreport/2018/june-2018 accessed: 17.12.2018).

5. Financial Stability Report. Bank of Italia.

https://www.bancaditalia.it/ pubblicazioni/rapportostabilita/inde x.html?com.dotmarketing.htmlpage .language $=1$ (Last accessed: 17.12.2018).

6. Financial Stability Report. Federa Reserve System. URL: https://www.federalreserve.gov/pu blications/financial-stabilityreport.htm (Last accessed: 20.12.2018).
7. Національний банк України. Звіт про фінансову стабільність НБУ. URL:

https://bank.gov.ua/control/uk/pub lish/category?cat_id=32236491 (дата звернення: 20.12.2018).

8. Demirgüç-Kunt, A., Beck, T., \& Honohan, P. Finance for All: Policies and Pitfalls in Expanding Access. Washington, D.C.: The World Bank. URL: http://sitere sources.worldbank.org/INTFINFORA LL/Resources/4099583-

1194373512632/FFA__ book.pdf (Last accessed: 25.12.2018).

9. Policy Research Report (PRR) on Access to Finance: Measurement, Impact and Policy Concept Note. URL:

http://worldbank.org/INTFR/Resour ces/PRR_on_

Access_to_Finance.pdf $+\& \mathrm{~cd}=1 \& \mathrm{hl}=\mathrm{r}$ $u \& c t=\bar{c} \operatorname{lnk} \& g l=u a \& c l i e n t=$ firefox $-b$ (Last accessed: 25.12.2018).

10. Rajan R., Zingales L. Financial dependence and growth. American Economic Review, № 88, 1998. P. 559-586.

11. Giovannini A., lacopetta M., Minetti R., Financial Markets, Banks, and Growth: disentangling the links. Revue de l'OFCE. URL: http://dx.doi.org/10.3917/reof.131. 0105 (Last accessed: 27.12.2018)
12. Bhaduri S. N. Investment, financial constraints and financial liberalization: some stulized facts from a developing economy. Journal of Asian Economics, №16, 2005. P. 704-718.

13. Greenwald B., Stiglitz J. E., Weiss A. Information imperfections in the capital market and macroeconomic fluctuations. American Economic Review, Vol. 74, 1984. P. 194-199.

14. Demirguc-Kunt A., Levine R. Financial structure and economic growth: A cross-country comparison of banks, markets and development. Cambridge: MIT Press, 2001.

15. Wurgler J. Financial markets and allocation of capital. Journal of Financial Economics. №58 (1-2), 2000. P. 187-214.

16. Lovea I., Zicchino L. Financial development and dynamic investment behavior: Evidence from panel VAR. The Quarterly Review of Economics and Finance. № 4. 2006. P. 190-210.

17. Demirguc-Kunt A., Maksimovic V. Funding grow thin bank-based and market-based financial systems: evidence from firm level data. URL: http://siteresources.worldbank.org/ DEC/Resources/ (Last accessed: 07.01.2019). 
www.econa.org.ua

18. Fan J., Titman S., Twite G. An international comparison of capital structure and debt maturity choices. NBER Working Paper, 2010. URL http://ihome.cuhk.edu.hk/ b10967 1/doc/ (Last accessed: 08.01.2019).

19. Almeida $\mathrm{H}_{\text {., }}$ Campello $\mathrm{M}$., Weisbach M. The cash flow sensitivity of cash. Journal of Finance, № 59(4), 2004. - P. 1777 1804.

20. Levine R. Bank-based or marketbased financial systems: Which is better? Journal of Financial Intermediation. № 11(4), 2002. P. 398-428.

21. Bauma C., Schaferb D., Talaverac O. The Impact of Financial Structure on Firms' Financial Constraints: A Cross-Country Analysis, 2009. URL: http://fmwww.bc.edu/ec-

p/wp690.pdf (Last accessed: 10.01.2019).
22. Chirinko R. Huntley S. Bubbles, fundamentals, and investment: $A$ multiple equation testing strategy. Journal of Monetary Economics, № 38, 1996.

23. Simon G., Himmelberg C. Evidence on the role of cash flow for investment. Journal of Monetary Economics, №36, 1995.

24. Hoshi T., Kashyap A., Scharfstein D. Corporate Structure, Liquidity, and Investment: Evidence from Japanese Industrial Groups. Quarterly Journal of Economics, №6, 1991.

25. Bond S., Elston J., Mulkay B. Financial factors and investment in Belgium, France, Germany and the UK: a comparison using company panel data. NBER, Working paper, 1997.
26. Kaplan S., Zingales L. Do investment Cash flow sensitivities provide useful measures of financing constraints? The Quarterly Journal of Economics, 112, 1997. P. 169 215.

27. Ivashkovskaya I., Kokoreva M. Capital Structure Policy in Central Europe and BRIC: Interaction of Internal determinants and Macroeconomic Factors. Proceedings of the 19th Annual Conference on Marketing an Business Strategies for Central\&Eastern Europe, Institute for Export Management, Vienna University of Economics and Business, 2011. P.173-202.

28. Положення НБУ «Про визначення банками України розміру кредитного ризику за активними банківськими операціями». URL: https://zakon.rada.gov.ua/laws/sho w/v0351500-16.

\section{REFERENCES}

1. Teplova, T. (2007). Jempiricheskoe issledovanie vlijanija finansovyh ogranichenij, opredeljaemyh razmerom kompanii, na investicionnoe povedenie na rossijskom rynke [An empirical study of the impact of financial constraints, determined by the size of a company, on investment behavior in the Russian market]. Upravlenie korporativnymi finansami - Corporate Finance Management, 4, 212-226. [in Russian]

2. Fazzari, S., Hubbard, R. G., Petersen, B. C. (1998). Financing constraints and corporate investment. Brookings Papers on Economic Activity, 1, 141-195.

3. The Financial Stability Review. (2018). European Central Bank. Retrieved from: https://www.ecb.europa.eu/pub/fsr /html/index.en.html (Last accessed: 15.12.2018).

4. Financial Stability Report. (2018) Bank of England. Retrieved from: https://www.bankofeng land.co.uk/financial-stabilityreport/2018/june-2018 accessed: 17.12.2018).

5. Financial Stability Report. Bank of Italia. (2018). Retrieved from: https://www.bancaditalia.it/ pubblicazioni/rapportostabilita/inde x.html?com.dotmarketing.htmlpage language $=1$ (Last accessed: 17.12.2018).
6. Financial Stability Report. Federal Reserve System. (2018). Retrieved from:

https://www.federalreserve.gov/pu blications/financial-stability-

report.htm (Last accessed: 20.12.2018).

7. Zvit pro finansovu stabil'nist' $N B U$ [NBU Financial Stability Report]. (2018). Natsional'nyy bank Ukrayiny. Retrieved from: https://bank.gov.ua/control/uk/pub lish/category?cat_id=32236491 (data zvernennya: 20.12.2018). [in Ukrainian]

8. Demirgüç-Kunt, A., Beck, T., \& Honohan, P. (2018). Finance for All: Policies and Pitfalls in Expanding Access. Washington, D.C.: The World Bank. Retrieved from: http://sitere

sources.worldbank.org/INTFINFORA LL/Resources/4099583

1194373512632/FFA_ book.pdf (Last accessed: 25.12.2018).

9. Policy Research Report (PRR) on Access to Finance: Measurement, Impact and Policy Concept Note. (2018). Retrieved from: http:// worldbank.org/INTFR/Resources/PR R_on

Access_to_Finance. $p d f+\& c d=1 \& h l=r$ $u \& c t=c|n k \& g|=u a \& c l i e n t=$ firefox $-b$ (Last accessed: 25.12.2018).

10. Rajan, R., Zingales, L. (1998). Financial dependence and growth. American Economic Review, 88, 559-586.
11. Giovannini, A., lacopetta, M. Minetti, R. (2018). Financia Markets, Banks, and Growth: disentangling the links. Revue de I"OFCE. Retrieved from: http://dx.doi.org/10.3917/reof.131. 0105 (Last accessed: 27.12.2018)

12. Bhaduri, S. N. (2005). Investment, financial constraints and financial liberalization: some stulized facts from a developing economy. Journal of Asian Economics, 16, 704-718.

13. Greenwald, B., Stiglitz, J. E., Weiss, A. (1984). Information imperfections in the capital market and macroeconomic fluctuations. American Economic Review, 74, 194-199.

14. Demirguc-Kunt, A., Levine, R. (2001). Financial structure and economic growth: A cross-country comparison of banks, markets and development. Cambridge: MIT Press, 2001.

15. Wurgler, J. (2000). Financial markets and allocation of capital. Journal of Financial Economics. 58 (1-2), 187214.

16. Lovea, I., Zicchino, L. (2006). Financial development and dynamic investment behavior: Evidence from panel VAR. The Quarterly Review of Economics and Finance, 4, 190210. 
www.econa.org.ua

17. Demirguc-Kunt, A., Maksimovic, V. (n.d.). Funding grow thin bankbased and market-based financial systems: evidence from firm level data. Retrieved from: http://siteresources.worldbank.org/ DEC/Resources/ (Last accessed: 07.01.2019).

18. Fan, J., Titman, S., Twite, G. (2010). An international comparison of capital structure and debt maturity choices. NBER Working Paper, Retrieved from: http://ihome.cuhk.edu.hk/ b10967 1/doc/ (Last accessed: 08.01.2019).

19. Almeida, H., Campello, M., Weisbach M. (2004). The cash flow sensitivity of cash. Journal of Finance, 59(4), $1777-1804$.

20. Levine, R. (2002). Bank-based or market-based financial systems: Which is better? Journal of Financial Intermediation, 11(4), 398-428.

21. Bauma, S., Schaferb, D., Talaverac, O. (2009). The Impact of Financial Structure on Firms" Financial Constraints: A CrossCountry Analysis. Retrieved from: http://fmwww.bc.edu/ec-

p/wp690.pdf (Last accessed: 10.01.2019).
22. Chirinko, R. Huntley, S. (1996). Bubbles, fundamentals, and investment: A multiple equation testing strategy. Journal of Monetary Economics, 38.

23. Simon, G., Himmelberg, S. (1995). Evidence on the role of cash flow for investment. Journal of Monetary Economics, 36.

24. Hoshi, T., Kashyap, A., Scharfstein, D. (1991). Corporate Structure, Liquidity, and Investment: Evidence from Japanese Industrial Groups. Quarterly Journal of Economics, 6.

25. Bond, S., Elston, J., Mulkay, B. (1997). Financial factors and investment in Belgium, France, Germany and the UK: a comparison using company panel data. NBER, Working paper, 1997.

26. Kaplan, S., Zingales, L. (1997). Do investment Cash flow sensitivities provide useful measures of financing constraints? The Quarterly Journal of Economics, 112, 169-215.
27. Ivashkovskaya, I., Kokoreva, M. (2011). Capital Structure Policy in Central Europe and BRIC: Interaction of Internal determinants and Macroeconomic Factors. Proceedings of the 19th Annual Conference on Marketing an Business Strategies for Central\&Eastern Europe, Institute for Export Management, Vienna University of Economics and Business, 173-202.

28. Polozhennya NBU «Pro vyznachennya bankamy Ukrayiny rozmiru kredytnoho ryzyku za aktyvnymy bankivs'kymy operatsiyamy» [NBU Regulation “On determining the size of credit risk by active banking operations by Ukrainian banks"]. (n.d.). Retrieved from:

https://zakon.rada.gov.ua/laws/sho w/v0351500-16. [in Ukrainian]. 